\title{
Fiscal impact of the migration phenomenon
}

\author{
Loredana Andreea Cristea \\ Department of Doctoral School, Faculty of Economic Sciences, \\ Lucian Blaga University of Sibiu \\ Romania \\ loredana.cristea@ulbsibiu.ro
}

\section{Janusz Grabara}

The Management Faculty, Czestochowa University of Technology,

Poland

janusz@grabara.eu

Abstract. The objective of this research has been to summarize the current situation regarding the migration phenomenon evolution and its relation to fiscal revenues and budget expenditures with social benefits, in six European Union member states. The purpose of this paper is to analyze the correlation between taxation and migration in Romania, Poland, Slovenia (emerging economies) and Germany, Italy, Spain (developed economies), as well as to present the proposals on how to optimize the fiscal effects of immigrants and emigrants, so that to ensure a balanced economy. The research methodology involves the use of descriptive, comparative and statistical techniques and through the statistical programs Eviews and SPSS, the data were interpreted using the regression analysis of the panel data. The analysis will be carried out over a longitudinal monthly period of 11 years, namely 1.01.2007-31.12.2017. This period includes the years of economic and financial global crisis, which have also been felt in European Union countries, as well as the years of economic recession. We conclude that the population from emerging countries is a long-term secure labor force for developed countries, while emigrants represent a net fiscal and economic loss for the countries of their origin. Furthermore, taxes and fees are not the main reasons that can influence people in deciding to choose the country where to live and work.

Keywords: migration, fiscal policy, fiscal revenues, social expenditures, European Union.

JEL Classification: F22, H20, H50 


\section{INTRODUCTION}

Human migration is a strongly rooted phenomenon in the world history, with significant effects on population`s standards of living, employment rates, economic development and budget balance, in both host and origin countries. This phenomenon has grown over the last decades and is unlikely to decrease, taking into account the economic, financial and demographic changes and imbalances faced by the European Union (EU) member countries. According to the OECD (2018), in 2017, around 258 million people around the world lived outside their country of residence or outside their country of origin, and the 2015-2016 refugee crisis became an additional test for migration, integration and asylum policies, especially for the EU countries.

Within the European Union, the increasing number of emigrants from emerging countries to developed ones has been favored by the free movement of people, which has made the entry to European labor market timely and easier, both for the citizens of developing countries and also for their employers. Freedom of movement for workers is also one of the founding principles of the European Union as such.

The aim of this study stems from the necessity to measure the influence of the migration phenomenon on the budgetary revenues of states and also on the fiscal policies implemented. This phenomenon was intensified after the economic and financial crisis and our main objective has been to analyze the situation during the 2007-2017 period in six EU member states, divided into two categories: emerging and developed economies.

High tax burden is mainly felt by the citizens of emerging countries. Besides this, the economic crisis of 2008-2009 has strongly hit the European Union countries as it aggravated their levels of corruption, tax evasion, public debt, also lowering their economic performance and reducing employment levels, by increasing the number of unemployed persons. The need to carry out this research stems from the fact that the phenomena of unemployment and the decreasing share of active population at the labor market, have intensified with the emigration of taxpayers. This, in turn, has made the fiscal burden on those who stayed even heavier.

It is often forecasted that immigration will affect government budgets in several ways. Thus, immigration of population can be seen from two points of view, namely:

- Positive, when a high number of legally employed migrants leads to higher fiscal revenues per capita, while reducing public debt and government spending;

- Negative, when immigrants retire, the impact on income will be negative and fiscal expenditures will be positive (Storesletten, 2000). However, the gap between the years of contribution and the years in which pension expenditure will be incurred is deep and the impact in this case is minimal.

The first part of the paper includes the study of the related literature on fiscal, social and economic impacts of the migration phenomenon and the results obtained by the researchers in previous studies. Then we will describe the evolution of the variables in the mentioned period, by:

- the comparative study of the number of emigrants and migrants in the six countries in question,

- the comparative study of the level of government revenues, namely fiscal revenues as a proportion of gross domestic product, as well as state expenditures on social benefits.

These comparative studies will help us in the analysis of the fiscal impact that the migration phenomenon may have.

The second part of the paper includes the analysis of the relationship between migration, fiscal revenues, income tax and social benefits expenditures with the help of regression analysis of the panel data. Finally, we will highlight the extent to which population migration represents (or not) a determinant factor of fiscal policy in the countries under study. 


\section{LITERATURE REVIEW}

According to the International Organization for Migration (IOM, 2004), most theorists and practitioners agree with the definition of migration as "the movement of a person or a group of people, either over an international border or within the state. It is a movement of the population, which includes every kind of movement of people, regardless of its duration, its composition and its causes".

Phenomenon of migration is widespread at global level and when we talk about it, we are directly thinking about emigrants and immigrants. An emigrant becomes an immigrant for the country in which he/she will settle and will produce positive and negative effects both in the host country as well as in the country of its origin. The emigrants' decision to leave the country of their origin is often influenced by factors such as:

- economic and financial constraints, resulting from low living standards, high unemployment rates, low public service quality, economical, financial and political instability, low employment opportunities;

- social factors, such as: wars, national conflicts, opportunities for a better future, proximity to family;

- environmental factors: natural disasters, weather conditions, etc. (Carling, 2016; Wallace, 2002).

Over time, the migration phenomenon and the effects it leaves behind, as well as its root causes, have been studied by several researchers (Cseh \& Papp et al., 2019). Economists agree that migration has strong effects on the economy, but there are many debates regarding the fiscal impact of migration and how emigrants and immigrants and their descendants affect the state budgets. For example, Nowrasteh (2015) argues that the economic benefits of immigration are unambiguous when its tax effects depend on the specifics of government policy over a long period. Because of this, the net fiscal impact of immigration could be negative, while the economic benefits are positive. Rowthorn (2008) concludes that the fiscal impact of immigration is highly positive in the host country, but in low proportions, compared to the economic impact.

Simionescu (2016) studied the macroeconomic determinants of permanent emigration from Romania. She led to the conclusion that low wages and poverty in the country are the main factors leading to the decision to leave the country of origin. In addition to these, profit and income taxes have significant pressure on the emigration decision.

Over time, the correlations between the main indicators with effect on the economy (Simionescu et al., 2017) and the system of taxes and fees have been studied and were made in order to highlight the influence of taxation on the economy (Cristea, 2019). For many authors, population migration is a cause as well as a factor of economic development (Massey et al., 2009; Glick Schiller \& Faist, 2012; Simionescu et al., 2016, 2018, 2019; Stakanov, 2018).

Michael \& Hatzipanayotou (2001) concluded that international migration is burdening for the well-being of the host country, by increasing the economic costs of various programs, such as health care and public education. This occurs even if the immigrants participate on budget revenues by paying taxes. At opposite side, international migration can hamper the ability of immigrants' country of origin to generate revenues from government taxes and to provide quality public goods.

Thomson (2011) explained that the most considerable influence in making the decision to emigrate has the family reasons and the family economic status. Taxes play an essential role if in the host country the government uses budget resources to deliver quality public services and to create jobs. However, the fiscal effects are low. On the other hand, the decision to emigrate is largely influenced by the net income expected in the host country (Grenčíková et al., 2017; Strielkowski \& Bilan, 2016; Streimikiene et al., 2016). Taxation in the origin country versus taxation in the host country may influence the migration decision, 
but according to Haapanen \& Ritsila (2001) its amplitude depends on the age of the individual, regional unemployment rate and level of net earnings.

Regarding the relationship between taxes and migration, Auerbach \& Oreopoulos (1999) concluded that immigration contributes to the tax burden felt by future generations and if the fiscal policy of accountability is respected, the tax pressure of immigrants is reduced. However, the impact of migration on the budgetary balance should not be seen as a significant source of influence. Still, Storesletten (2000) has demonstrated that immigration policy has substantial quantitative implications on fiscal policy and this must be seen as a determinant of state budget revenues.

Krause (2017) concluded that the increasing international mobility of highly qualified individuals is hindering the ability of the government to form its tax revenues. Also, this mobility affects the social and economic well-being of the country.

Wallace (2002) analyzed over a period of more than five years if income taxes in Georgia influences the individual's decision to migrate. He concluded that in some areas of the country, high wages of employees offset the high-income tax and this fact explains why in many studies the taxation did not have a significant effect on the migration phenomenon. Ruiz del Portal (2017) studied the optimal model of income tax and concluded that migration encourages the supply of public goods, but all this phenomenon leads to violations of the tax rules, by those remaining in the country of origin.

Gabszewicz et al. (2016) concluded that taxation is still influenced by migration but also by the country's productivity. For example, when emigrants leave low-income countries, for highly productive countries, emigration reduces income tax rates in their country of origin and increases income tax rates in the state of destination. On the other hand, compared to the scenario of a fiscal balance without productivity gaps, when emigrants leave high productivity countries in favor of low-productivity countries, migration increases income tax in their country of origin and lowers income tax in the state of destination.

On the other hand, Phyo et al. (2019) used panel data from 72 countries, to study the relationship between migration, the level of economic development and foreign direct investment. They concluded that the more an emerging economy develops, the less the brain drain phenomenon will decrease. They also showed that there is a positive relationship between a developed economy and the phenomenon of migration. Thus, we can say that the more it is developed, the more the number of immigrants increases and the number of emigrants decreases.

By this research, our aim is to highlight the extent to which population migration represents (or not) a determinant factor of fiscal policy in the countries under study.

\section{CURRENT SITUATION AND GENERAL CONSIDERATIONS}

In the first part of the research, the study is based on the use of descriptive, comparative and statistical techniques, through their graphs, tables and interpretations. Forwards, we will illustrate the current situation, regarding the research topic, namely the evolution in time of emigrants, immigrants flow, as well as the evolutions of fiscal revenues, income taxes and budget expenditures on social protection benefits. The highlight of the evolution is made to delimit the general considerations of the current situation of the study.

The economic crisis has left deep marks within the European Union. Through the comparative study, we will be able to outline the trajectories recorded after the economic crisis and to highlight the effects on migration. Also, we will be able to highlight the fiscal policy adopted by the government of the developed and emerging economies on income tax and social expenditures.

We selected for the study six European Union member states: Romania, Poland, Slovenia, Germany, Italy and Spain. The reason for choosing these countries is due to the fact that we intended to include in 
the research both developed and developing economies. Also, we selected in the study, especially those countries with a large number of immigrants and emigrants. Thus, in each category, we selected three countries. According to the International Monetary Fund (IMF), their 2018 rating is:

- emerging economies - Romania, Poland and Slovenia;

- developed economies - Germany, Italy and Spain.

The data that we use in this paper was taken from the database of European Commission`s office responsible for statistics (Eurostat) and from the Organization for Economic Cooperation and Development (OECD) database.

\subsection{Considerations post-economic and financial crisis, regarding the migration situation}

In Table 1, we point out the emigration movement of people from the analyzed countries. According to European Commission, the emigration represents the action of a person to leave their origin country, thus establishing their residence in another EU Member State or a third country, for at least 12 months. The number of emigrants is expressed in total number of persons that includes both emigrants from the state of origin and emigrants coming from other EU Member States or outside the EU.

As can be seen, the number of emigrants in developed countries is noticeably higher than in the emerging ones. For example, the exodus of population is being almost double in Germany and Spain, compared to Poland and Romania. Exception to the large number of emigrants in developed economies is Italy, which in the 11-years study followed a slightly upward trend, regarding the number of people leaving the country. This fact show that the Italian government practices social, economic and financial policies in favor of the resident population and the traces left by the economic crisis, also present in Italy, have not encouraged the population to choose the living conditions provided by other countries. Another exception is Slovenia, which has the lowest number of emigrants, a total of 163,939 people in the postcrisis period. However, these should not be misleading, considering that in 2018, the estimated number of total population of Slovenia is around 2 million persons, far below the other countries under study.

Table 1

Evolution of emigrants flow during 2007-2017 (by reporting country- thousand persons)

\begin{tabular}{|c|c|c|c|c|c|c|}
\hline EMIGRANTS & Germany & Spain & Italy & Poland & Romania & Slovenia \\
\hline 2007 & 636.854 & 227.065 & 51.113 & 35.480 & $*$ & 14.943 \\
\hline 2008 & $\mathbf{7 3 7 . 8 8 9}$ & 288.432 & 80.947 & $*$ & $\mathbf{3 0 2 . 7 9 6}$ & 12.109 \\
\hline 2009 & 286.582 & 380.121 & 80.597 & 229.320 & 246.626 & 18.788 \\
\hline 2010 & 252.456 & 403.377 & 78.771 & 218.126 & 197.985 & 15.937 \\
\hline 2011 & 249.045 & 409.034 & 82.461 & 265.798 & 195.551 & 12.024 \\
\hline 2012 & 240.001 & 446.606 & 106.216 & 275.603 & 170.186 & 14.378 \\
\hline 2013 & 259.328 & $\mathbf{5 3 2 . 3 0 3}$ & 125.735 & $\mathbf{2 7 6 . 4 4 6}$ & 161.755 & 13.384 \\
\hline 2014 & 324.221 & 400.430 & 136.328 & 268.299 & 172.871 & 14.336 \\
\hline 2015 & 347.162 & 343.875 & 146.955 & 258.837 & 194.718 & 14.913 \\
\hline 2016 & 533.762 & 327.325 & 157.065 & 236.441 & 207.578 & 15.572 \\
\hline 2017 & 560.700 & 368.860 & 155.110 & 218.492 & 242.193 & 17.555 \\
\hline TOTAL & $\mathbf{4 . 4 2 8 . 0 0 0}$ & $\mathbf{4 . 1 2 7 . 4 2 8}$ & $\mathbf{1 . 2 0 1 . 2 9 8}$ & $\mathbf{2 . 2 8 2 . 8 4 2}$ & $\mathbf{2 . 0 9 2 . 2 5 9}$ & $\mathbf{1 6 3 . 9 3 9}$ \\
\hline
\end{tabular}

Source: Eurostat, OECD database; ${ }^{*}$ - unavailable data

It can be noticed that the number of Polish emigrants from 2009, the year most formally affected by the economic and financial crisis, compared to 2007, it is about 6.5 times higher. Until 2017, every year, in Poland, the number of population that decides to emigrate was at the annual value of approx. 250 
thousand people. According to the International Migration Outlook (IMO, 2018), on December 2016, more than 2.5 million Polish citizens lived across the country, with leading destinations: United Kingdom $(31 \%)$ and Germany (27\%). The number of 2,5 million emigrants is close to the one encountered in Romania. On the one hand, this fact highlights the migration boom caused by the economic crisis and, on the other hand, Romania's accession to the EU and the opening of cross-border within it. The central destination countries for Romanian emigrants are Italy and Spain.

Taking into account the data provided by the European Commission through the Eurostat database, the number of emigrants with the same nationality as the origin country is considerably lower for developed economies, and their residents are not tempted to leave their country of origin. An opposite situation is found in emerging countries, where the vast majority of emigrants are being formed by citizens of those states. For example, the most significant boom in terms of residents' emigration is met for Romanian citizens, 300 thousand people decided to leave the country in 2008, followed by German citizens (171 thousand people), then by citizens of Poland (67 thousand). Both the number of Romanian and Polish citizens, who have decided to emigrate in each year, have a close value to the total number of emigrants (for example, in Romania, the year 2017 was characterized by a total emigration of 242,193 persons, among which 221,798 were Romanian citizens).

In table 2, we show the phenomenon of immigration and according to the European Commission, it represents the action of persons, in the countries under consideration, to establish their residence in an EU Member State or a third country outside the country of their origin, for at least 12 months. The number of immigrants is expressed in total number of persons and includes both immigrants from the state of origin and immigrants coming from other EU Member States or from outside the EU.

Table 2

Evolution of immigrants flow in 2007-2017 (thousand persons)

\begin{tabular}{|l|c|c|c|c|c|c|}
\hline IMMIGRANTS & Germany & Spain & Italy & Poland & Romania & Slovenia \\
\hline 2007 & 680.766 & $\mathbf{9 5 8 . 2 6 6}$ & 527.123 & 14.995 & $*$ & 29.193 \\
\hline 2008 & 682.146 & 599.075 & $\mathbf{5 3 4 . 7 1 2}$ & 15.275 & 138.929 & 30.693 \\
\hline 2009 & 346.216 & 392.962 & 442.940 & 189.166 & 135.844 & 30.296 \\
\hline 2010 & 404.055 & 360.705 & 458.856 & 155.131 & 149.885 & 15.416 \\
\hline 2011 & 489.422 & 371.331 & 385.793 & 157.059 & 147.685 & 14.083 \\
\hline 2012 & 592.175 & 304.053 & 350.772 & 217.546 & 167.266 & 15.022 \\
\hline 2013 & 692.713 & 280.772 & 307.454 & 220.311 & 153.646 & 13.871 \\
\hline 2014 & 884.893 & 305.454 & 277.631 & 222.275 & 136.035 & 13.846 \\
\hline 2015 & $\mathbf{1 . 5 4 3 . 8 4 8}$ & 342.114 & 280.078 & 218.147 & 132.795 & 15.420 \\
\hline 2016 & 1.029 .852 & 414.746 & 300.823 & 208.302 & 137.455 & 16.623 \\
\hline 2017 & 917.109 & 532.132 & 343.440 & 209.353 & 177.435 & 18.808 \\
\hline TOTAL & $\mathbf{8 . 2 6 3 . 1 9 5}$ & $\mathbf{4 . 8 6 1 . 6 1 0}$ & $\mathbf{4 . 2 0 9 . 6 2 2}$ & $\mathbf{1 . 8 2 7 . 5 6 0}$ & $\mathbf{1 . 4 7 6 . 9 7 5}$ & $\mathbf{2 1 3 . 2 7 1}$ \\
\hline
\end{tabular}

Source: Eurostat, OECD database; * - unavailable data

According to the above table, the developed countries represent an attraction for immigrants and the total number, in the 11 years studied, is being around 4 million for Italy and Spain and 8 million for Germany.

In Italy, according to IMO (2018), most of the immigrants are Romanians, namely 1.7 million. For Spain year 2016 was the year when most Spanish citizens decided to return home. This return was encouraged by the implementation of the government's economic and financial policies in order to reduce the deep marks of the 2008-2009 economic crisis, namely the higher rates of unemployment, above the rates of the EU-28 (Eurostat, 2019). 
The biggest boom of immigrants is in Germany of 2015-2017, years characterized by the "refugee crisis" from Syria, Iraq and Afghanistan. However, according to IMO (2018), in 2016, most immigrants came from Romania (222,400), Syria (179,400), Poland $(160,700)$ and Bulgaria $(83,000)$. Germany has registered a total of 8 million immigrants during the period under study, which with the unemployment rate, is in an inversely proportional relationship. According to Eurostat data, the unemployment rate was decreasing from $8.5 \%$ in 2007 to $3.8 \%$ in 2017 , while the number of immigrants has increased from year to year.

Also, in the case of the number of immigrants, Slovenia has the lowest number, relatively constant during the recession period and after that, namely 2009-2017. The low number of immigrants encountered is because Slovenia is more a transit country for European migrants, non-European and refugee countries. This thing is happening because the migrants continue their journey to the developed nations in Northern Europe.

Regarding the situation in Romania and Poland, in each year analyzed, the number of immigrants is lower than that of emigrants, with net migration's values being negative. The economically developed countries offer the possibility of a better living, through the public services provided and by the level of net salary. These are better in comparison with the emerging economies and the population from Romania, Poland and Slovenia but generally, the population of the emerging countries is a secure workforce for a long time. For countries of origin, the emigrants are a net loss. This fact can highlight the inability of the state to promote optimum conditions in terms of economic, financial and social, to encourage people to return or stay "home".

\subsection{The evolution of fiscal revenues and expenditures on social protection benefits,} during 2007-2017 period

According to the OECD (2019), the definition of fiscal revenues refers to the revenues collected from taxes on income and profits, social security contributions, taxes on goods and services, wage taxes, property taxes and property transfers, as well as other taxes. In this study, it was chosen to use fiscal revenues (excluding social security contributions) as a percentage of GDP. This indicator indicates the share of a country's output, collected by the government through taxes. This indicator can be considered a measure of the degree to which the government controls the resources of the economy and the financial resources available. All this resources are in order to cover public expenditures and to provide quality public services.

According to Eurostat (2019), social protection includes all interventions by public or private bodies designed to relieve households and individuals of the burden of a set of risks or needs. The eight main recognized risks and needs are sickness/medical care, disability, old age, survivors, family/children, unemployment, housing and social exclusion.

In table 3, we summarize the evolution of tax revenues and budget expenditures on social protection benefits. The economic crisis, together with the fiscal policy measures adopted in the countries under study, changes in legislation or economic activity, had a later impact on tax revenues. Although the first effects of the crisis, at the level of the European Union, have been visible since 2008, these consequences on tax revenues were met in 2009-2010, when the first decreases were recorded.

In Italy, the share of tax revenues in GDP is higher than the EU28 average, in all the years under review. These values mean that the Italian government has made a significant effort to ensure an attractive tax policy for both immigrants and the resident population. The fiscal revenues' situation is in line with the level of migration in Italy. These high proportions of tax revenues in GDP (ranging from $28.43 \%$ to 
$30.38 \%$ ) highlight a substantial contribution of the citizens to the formation of fiscal revenues, both in terms of taxes on income, profit, and mainly due to consumption taxes.

Proportions over 21\% of fiscal revenue in GDP are in Germany, Spain and Slovenia, with the only exceptions being Poland and Romania, with lower proportions. A repercussion of low fiscal revenues in GDP, in these two countries, could be caused by:

- the non-coverage of budget expenditures;

- the rise of public debt at a burdening level for the resident population;

- the level of migration throughout the analyzed period.

Both countries have had a higher number of emigrants than immigrants. This fact can suggest either that the fiscal policy of the state is ineffective or the economic, political and social situation, corruption and underground economy led to discouraging citizens from deciding to pursue activities in their country of origin.

Many causes can make the government's fiscal revenues vary from year to year. For a detailed analysis, it would be necessary to explain the internal causes in each country. In general, the main reasons are:

- changes in economic activity that may affect employment rates, migration levels, level of investment, consumption level, sale of goods and services, etc.;

- fiscal legislation (through tax rates, tax base, exemptions), which can influence the salary levels, the emergence of tax evasion, the consumption discouragement, etc., all of which have an impact on the welfare of taxpayers.

Table 3

Evolution of fiscal revenues (excluding social security contributions) and expenditures on social protection benefits ( $\%$ GDP)

\begin{tabular}{|c|c|c|c|c|c|c|c|c|c|c|c|}
\hline & 2007 & 2008 & 2009 & 2010 & 2011 & 2012 & 2013 & 2014 & 2015 & 2016 & 2017 \\
\hline \multicolumn{12}{|c|}{ Fiscal Revenues } \\
\hline EU28 & 26.56 & 26.05 & 25.03 & 25.29 & 25.72 & 26.25 & 26.62 & 26.64 & 26.69 & 26.77 & 26.95 \\
\hline Germany & 22.74 & 23.06 & 22.71 & 21.72 & 22.32 & 22.82 & 23.19 & 23.08 & 23.33 & 23.60 & 23.78 \\
\hline Spain & 24.95 & 20.72 & 18.50 & 20.07 & 19.99 & 21.18 & 22.09 & 22.40 & 22.71 & 22.30 & 22.48 \\
\hline Italy & 29.04 & 28.43 & 28.49 & 28.43 & 28.53 & 30.38 & 30.34 & 30.19 & 30.00 & 29.48 & 29.27 \\
\hline Poland & 22.83 & 22.91 & 20.12 & 20.62 & 20.73 & 20.13 & 19.71 & 19.77 & 19.94 & 20.84 & 21.33 \\
\hline Romania & 18.79 & 17.78 & 16.26 & 17.75 & 19.23 & 19.03 & 18.68 & 18.95 & 19.92 & 17.77 & 16.45 \\
\hline Slovenia & 23.70 & 22.91 & 21.86 & 22.30 & 22.05 & 22.18 & 22.14 & 22.18 & 22.15 & 22.27 & 21.99 \\
\hline \multicolumn{12}{|c|}{ Expenditures on social protection benefits } \\
\hline EU28 & & 24.8 & 27.5 & 27.4 & 27.2 & 27.6 & 27.8 & 27.6 & 27.4 & 27.1 & $:$ \\
\hline Germany & 25.8 & 26.1 & 29.3 & 28.6 & 27.5 & 27.6 & 27.9 & 27.7 & 28 & 28.2 & $:$ \\
\hline Spain & 19.8 & 21 & 24 & 24.2 & 24.9 & 25 & 25.3 & 24.9 & 24.2 & 23.9 & $:$ \\
\hline Italy & 24.5 & 25.5 & 27.5 & 27.6 & 27.4 & 28.1 & 28.6 & 28.8 & 28.8 & 28.6 & $:$ \\
\hline Poland & 17.9 & 18.8 & 19.8 & 19.2 & 18.2 & 18.4 & 19.1 & 18.9 & 19 & 19.9 & $:$ \\
\hline Romania & 12.8 & 13.6 & 16.2 & 17.3 & 16.3 & 15.2 & 14.6 & 14.4 & 14.3 & 14.3 & : \\
\hline Slovenia & 20.4 & 20.5 & 23.2 & 23.9 & 24.1 & 24.4 & 24.3 & 23.5 & 23.3 & 22.9 & : \\
\hline
\end{tabular}

Source: Eurostat database; : - unavailable data.

As can be seen in table 3, in 2008-2016 period the EU28 average of social protection expenditures slightly increased at a relatively constant pace, from $24.8 \%$ to $27.1 \%$, as a percentage of GDP. The two primary sources of social protection funding at the EU level were social contributions and government contributions generated by taxes. An unusual situation can be noticed, although unemployment rates are higher for emerging economies; the share of social protection expenditure in GDP is higher for developed ones. These differences may derive from different living standards, the national social protection systems 
and the demographic, economic, social and institutional structures specific to each Member State. According to Eurostat, not all government expenditure functions evolved in the same way between 2007 and 2016. Some functions had a natural tendency to be anti-cyclical, even without a change in financial policy. For example, government expenditures on unemployment (part of social protection) are predisposed to have an anti-cyclical evolution than other functions (such as public expenditures on education). This evolution is resulting from the fact that more people become unemployed during an economic crisis, while the number of pupils and students is more affected by demographic change.

\section{METHODOLOGY}

In the first part of the paper, we illustrated the situation regarding the subject of research, namely the evolution in time of emigrants and immigrants flow, as well as the evolutions of fiscal revenues, income taxes and budget expenditures on social protection benefits:

The second part of the research will be materialized through the regression analysis of the panel data between migration and taxation. This analysis is obtained with the help of Eviews software. The analysis of the empirical literature studied above gives us an overview of the phenomenon of emigration and taxation. Thus, through this research we want to highlight the effect of emigration and immigration on fiscal policies. Achieving this goal depends on the specification of the chosen model. Thus, the use of regression analysis of panel data will make it possible to determine the interconnections between model variables.

Data on emigrants (EMIG) and immigrants (IMIG) is expressed in the total number of people, and tax revenues (REV), revenue collected from income taxes (IMP) and social protection expenditure (EXP) are expressed as a percentage of gross domestic product (GDP). Our study will involve comparing the results obtained in the countries under analyze, focusing on their grouping, according to the level of development (emerging economies and developed economies).

Because the migration phenomenon assessment in Romania is limited by the short official data (Simionescu, 2016) our analysis will be carried out over a longitudinal monthly period of 11 years, i.e. 01.01.2007-31.12.2017. This period will include the years of global economic and financial crisis, which have also been felt in the European Union countries, as well as the years of economic recession. The monthly data was obtained by transforming the annual data into monthly data, using the E-views software`s functions.

In order to achieve the proposed objective, with the help of the statistical program for social sciences SPSS, we studied the Pearson correlation between the model variables, at the level of the six countries, starting from 3 null hypotheses, namely:

$\mathrm{H}_{0} 1$ : There is no correlation between income taxes and migration;

$\mathrm{H}_{0} 2$ : There is no correlation between tax revenues and migration;

$\mathrm{H}_{0} 3$ : There is no correlation between expenditure on social protection and migration. 
Pearson Correlation between model's variables

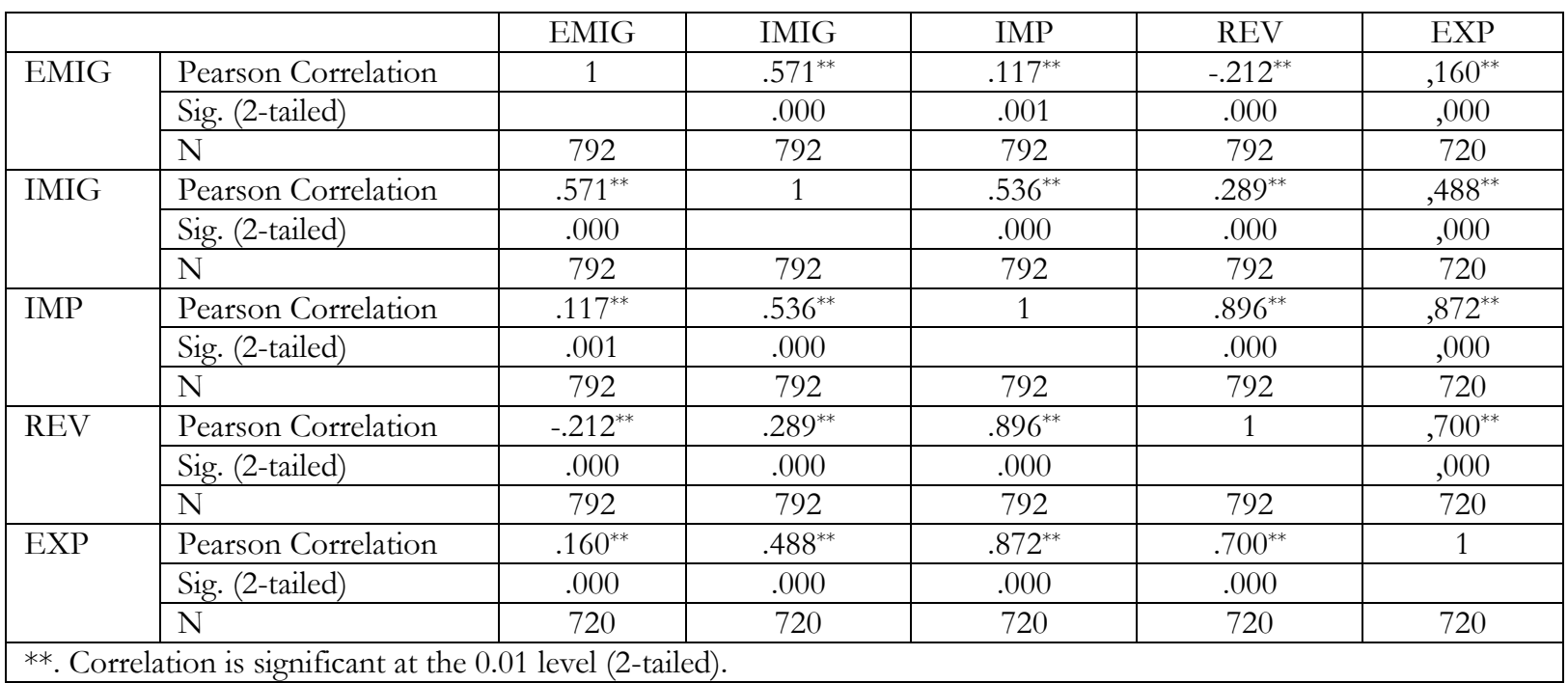

Source: Autors own processing, using SPSS software

As can be seen in table no. 4, there are significant correlations between the variables chosen in the model at the level of the analyzed countries. The value of Sig is 0.000 in all cases, respectively $\mathrm{p}<0.05$, which means that there is a statistically significant correlation between the analyzed variables. The null hypotheses are rejected.

If we consider the variables regarding the income tax and migration, we can see that for the variables IMP and EMIG, the Pearson coefficient with $r=0,117$, according to Cohen (1988), shows that the relation between them is positive, but minor and the association is low. Moreover, in the case of the variables IMP and IMIG, the Pearson coefficient with $\mathrm{r}=0.536$ shows that the relationship between the variables is positive and high, and the association is great.

If we consider the variables related to tax revenues and migration, we can see that in the case of the variables REV and EMIG, the Pearson coefficient with $r=-0.212$ shows that the relation between them is negative and minor, and the association is low. Moreover, in the case of the variables REV and IMIG, the Pearson coefficient with $r=0.289$ shows that the relation between them is positive and minor, and the association is low.

If we consider the variables regarding the expenditures with social protection and migration, we can observe that: in the case of the variables EXP and EMIG, the Pearson coefficient with $r=0,160$ shows that the relation between them is positive and minor, and the association is low. Furthermore, for EXP and IMIG variables, the Pearson coefficient with $r=0.488$ shows that the relationship between them is positive and moderate, and the association is average.

Following the interpretation of table 4, we concluded that although there are correlations between taxation and migration, they are not very strong. In order to identify, in-depth, the fiscal effects of migration by category of countries (emerging economies and developed economies), the panel regression analysis was used, using the statistical program Eviews.

In the regression analysis, from the last part of the paper, we will use panel data series.

To eliminate the seasonal effects, we resorted to the seasonal adjustment of the model variables, in order to capture the real evolution from the consecutive periods, of the studied indicators. Before starting 
the model estimation, the variables were logarithmized. Also, the normal data distribution was verified with the help of the Kolmogorov-Smirnov test, from the SPSS statistical program.

Using the regression analysis of panel data, it will help us to estimate the relationships between the dependent variable (of fiscal nature) and the independent variables (of migratory nature). Dependent variables were: tax revenues (REV), income taxes (IMP) and social benefits expenditures (EXP), and independent variables: number of immigrants (IMIG) and number of emigrants (EMIG).

Panel data refers to a series of multidimensional data over a period of 11 monthly years. In our case, we have about 132 observations for each analyzed country $=>396$ observations in each group of emerging/developed countries.

The regression equation for panel data is in the following form $\mathbf{Y}_{\mathrm{it}}=\mathbf{a}+\mathbf{b X} \mathbf{1}_{\mathrm{it}}+\ldots+\mathrm{Xn}_{\mathrm{it}}+\mathrm{e}_{\mathrm{it}}$, where:

- $\quad$ Y represents the dependent variable;

- $\quad \mathrm{X} 1 \ldots \mathrm{Xn}$ represents the independent variables;

- $\quad a, b$ - the regression coefficient (the amount with which $\mathrm{Y}$ will changes when $\mathrm{X}$ changes with one unit);

- $\quad \mathrm{e}$ is the term of error

- the index " $\mathrm{i}$ " shows the cross-sectional dimension and the index " $t$ " the temporal one

To see which model is most compatible with the panel data we have, we applied the DurbinHausman test (Durbin, 1954; Hausman, 1986). In our case, the null hypothesis (Ho: Random effects model is appropriate) was rejected, and the alternative hypothesis was accepted $\left(\mathrm{H}_{\mathrm{A}}\right.$ : Fixed effects model is appropriate), so the fixed effects model is best suited for our sample.

\section{EMPIRICAL RESULTS AND DISCUSSION}

Through the empirical analysis of this paper, we seek to establish the link between taxation and migration. We start from the fact that emigration is a phenomenon increasingly practiced in emerging economies, and the number of immigrants in the developed economies is at the order of millions. In the first place, we need to identify the link between migration and fiscal revenues, as well as income taxes, and secondly, by identifying the degree of influence exerted by migration on social protection expenditures.

In order to achieve the proposed objective, using the regression analysis of panel data, respectively fixed effects model, we study:

- the relationship between migration and income taxes in the developed economies, then in the emerging economies;

- the relationship between migration and fiscal revenues in the developed economies, then in the emerging economies;

- the relationship between migration and social protection expenditures at the level of the developed economies, then at the level of the emerging economies.

In table 5, we resorted to making two regression models of panel data, as follows: at the level of developed countries and the level of emerging countries. Using the fixed-effects model, we assume that with this model, the parameters are fixed alternately, and the average of the groups is fixed. To observe the degree of influence of the independent variables on the dependent variable, we will consider the coefficient of determination $\mathrm{R}^{2}$ and the $\mathrm{p}$-value. For the variable to be included in the model, the $\mathrm{p}$-value must be less than $\alpha(\alpha=0.05)$. 
Relationship between the fiscal variables and migration

\begin{tabular}{|l|c|c|c|c|c|}
\hline \multirow{2}{*}{ Dependent Variables } & \multicolumn{2}{c|}{ Independent variables } & \multirow{2}{*}{$\mathbf{R}^{\mathbf{2}}$} & \multicolumn{2}{c|}{ p-value } \\
\cline { 2 - 6 } & EMIG & \multicolumn{2}{c|}{ IMIG } & & \multicolumn{2}{c|}{ EMIG } & \multicolumn{1}{c|}{ IMIG } \\
\hline \multicolumn{7}{|c|}{ Emerging economies (Romania, Poland, Slovacia) } \\
\hline REV & - & + & 0.856 & 0.0000 & 0.0007 \\
\hline IMP & - & + & 0.947 & 0.0000 & 0.0001 \\
\hline EXP & + & - & 0.898 & 0.0000 & 0.0000 \\
\hline \multicolumn{7}{|c|}{ Developed economies (Germany, Italy, Spain) } \\
\hline REV & + & + & 0.885 & 0.0166 & 0.0000 \\
\hline IMP & + & + & 0.970 & 0.0000 & 0.0000 \\
\hline EXP & + & - & 0.807 & 0.0000 & 0.0000 \\
\hline
\end{tabular}

Source: Authors own precessing, using Eviews software

Given that, in all cases, the p-value was below the 0.05 threshold, so we included all variables in the model. Next, we have analyzed the two groups of economies. In the case of emerging countries, the following relations have resulted:

$$
\text { LOG }(\mathrm{REV})=4.01239-0.10956 * \text { LOG }(\text { EMIG })+0.02144 * \text { LOG }(\mathrm{IMIG})
$$

According to the relation (1), regarding the dependent variable REV, the coefficient of determination $\mathrm{R}^{2}$ of $85.6 \%$ shows a statistically significant correlation between the variables. In the case of the variable EMIG, the existing relationship is inversely proportional. This means that an increase in the number of emigrants by one unit of measure will lead to a decrease in tax revenues by 0.10956 units. In the case of the IMIG variable, the relationship is positive, which means that an increase of immigrants will lead to an increase of the fiscal revenues to the state budget, by 0.02144 units.

$$
\text { LOG }(\text { IMP })=2.35952-0.10757 * \text { LOG }(\text { EMIG })+0.03096 * \text { LOG }(\text { IMIG })
$$

In relation (2), the determination coefficient $\mathrm{R}^{2}$ of $94.7 \%$ shows a robust correlation between the variable IMP and the variables related to the migration phenomenon. Also, in this case, there is a negative relationship between emigrants and the dependent variable and a positive one between immigrants and income taxes.

By analyzing the first two relationships, we have seen that the higher number of emigrants, as compared to that of immigrants, has unfavorable fiscal effects. These can be translated by the decreasing labor force in the emerging economies, which prefer to leave the country of their origin for various reasons, especially related to the higher net income, received in the host country. At this conclusion reached also Grenčíková et al.. (2017).

$$
\text { LOG }(\mathrm{EXP})=2.64582+0.06957 * \text { LOG }(\mathrm{EMIG})-0.04422 * \text { LOG }(\mathrm{IMIG})
$$

As for the relationship (3), the situation is the opposite. The variable EMIG is in a positive association with social protection expenditures. However, the increase of one unit of the variable IMIG leads to a decrease of 0.03096 units of the EXP variable. This relationship is strengthened by the value of the coefficient of determination of $89.9 \%$.

$$
\text { LOG }(\mathrm{REV})=2.3839+0.01746 * \text { LOG }(\mathrm{EMIG})+0.04537 * \text { LOG }(\mathrm{IMIG})
$$

Regarding the analysis of the situation in developed economies, according to relations (4) and (5), migration has a positive impact on tax revenues and income taxes, but still inferior to other factors. This evidence results from the fact that the model constant is higher than the regression coefficients of the independent variables. It means that a change in other factors not included in the model will increase the tax revenues by 2,3839 units, respectively will increase the income taxes by 1,10435 units.

$$
\text { LOG }(\mathrm{IMP})=1.10435+0.06562 * \mathrm{LOG}(\mathrm{EMIG})+0.02199 * \text { LOG }(\mathrm{IMIG})
$$


As in the case of the emerging countries (relation 3), in the developed countries, the impact of immigrants on social benefits expenditures is in inverse proportional correlation (relation 6), The negative influence of the IMIG variable, observed in the developing economies and developed economies, can be influenced by the increase in the number of employees in the country and the decrease in the number of unemployed. In this situation, although the tax revenues increase, the social benefits expenditures decrease, but at the same time, we can speak about an increase of other categories of public expenditure, which were not analyzed in this study. These would be public education expenditures and public health expenditures.

$$
\text { LOG }(\mathrm{EXP})=4.19506+0.03697 * \text { LOG }(\mathrm{EMIG})-0.10623 * \text { LOG }(\mathrm{IMIG})
$$

The results obtained in the case of the emerging economies, namely, the decrease of the tax revenues and income taxes once the population is leaving the country of their origin, are in line with previous studies (Gibson \& McKenzie, 2012; Clements et al., 2015). The inverse relationship between EMIG, REV and IMP is because the population left behind, in their origin country, cannot help in the formation of government revenues without the tax burden making its presence felt.

We can justify the negative relationship between the number of emigrants and dependent fiscal variables by the fact that an increase in the number of people who decide to leave for some time (the country of their origin or the host country) can only lead to drops in all levels. We also concluded that the adverse fiscal effects would be even more substantial in the emerging countries. This result is because the labor force is lost and the number of immigrants does not exceed the number of emigrants.

Looking by analogy, in the case of developed economies, both emigrants and immigrants have positive fiscal effects. It is understandable because, through the applied social policies, but also because the number of immigrants is lower than the number of immigrants, the fiscal effects are balanced and positive. This result it is also in line with the previous study by Phyo et al. (2019).

Regarding the positive relationship between immigrants and tax revenues and income taxes, for all the six countries analyzed is understandable (Hansen et al., 2015). On the one hand, the increase of fiscal variables results from the direct and indirect taxes paid by immigrants through their expenditures. On the other hand, an increase in the number of employees on the labor market, in the registered economy, means more taxpayers and more resources for the formation of government revenues through the payment of taxes and social contributions. Also, signifies even more public services, where the taxpayers are direct beneficiaries of them.

The constant obtained in the six relations, presented above, is higher than the regression coefficients for the independent variables. Overall, the fiscal impact of the migration phenomenon tends to be small compared to other factors, which we did not take into account in the present research. These factors can be inflation, wage level, economic stability, public debt, tax bases, number of employees, along with others.

\section{CONCLUSIONS}

The estimation of the taxation and migration correlation is difficult because of the limited data and the leading causes, behind the decision to leave the country of origin, are diverse and vary within the emigrant population. The population is different from the point of view of professional training, age, level of education and personal aspirations. Taxes and fees are not the main reasons that can influence people in deciding to choose the country where they live and work.

Immigrants can generate fiscal effects in host countries, being both beneficiaries of public services (funded from budget revenues) and taxpayers for government revenues generation (by paying taxes, fees and social security contributions). The fiscal effects of immigrants and emigrants can be positive or 
negative depending on: the policies promoted by host countries; the level and type of taxes and fees; the dynamics of the labor market; economic and social factors; the living standards and their social characteristics, but these fiscal effects are still low.

The main conclusion reached is that the emigrants produce negative effects in the emerging economies and positive effects in the developed countries. This results from the fact that, in the case of developed economies, the number of immigrants is higher than that of emigrants. So, the emigrants' flow do not have substantial effects on tax revenues. It was concluded that although there are correlations between taxation and migration, they are not very strong. However, this highlights that migration can have significant effects on the country's incomes, social, economic and demographic well-being, but also on the redistribution of incomes. These assumptions are in line with previous studies (Uprety, 2019; Gnimassoun \& Anyanwu, 2019).

The economically developed countries offer the possibility of a better living, through the public services provided and by the level of net salary. These are better in comparison with the emerging economies and the population from Romania, Poland and Slovenia but generally, the population of the emerging countries is a secure workforce for a long time. For countries of origin, the emigrants are a net loss. This fact can highlight the inability of the state to promote optimum conditions in terms of economic, financial and social, to encourage people to return or stay "home".

The developed economies have resorted to attracting immigrants to cover their economic needs. We think that these needs are related to the lack of highly skilled labor, but also to the unskilled labor force, especially in the agriculture and construction sector. The migration attraction is made either through public services offered (such as those related to health and education), which can be materialized through taxation, either by tax incentives for immigrants, including wage levels. These measures, taken by developed economies, led directly to an increase in the number of immigrants and a decrease in the number of emigrants. In recent years, they also have recourse to attract highly skilled labor, by providing high-quality public services and wage benefits, superior to the origin countries of immigrants. This fact leads to the phenomenon of "brain-drain" an increasing phenomenon more and more studied in the present (Basile et al, 2019; Cattaneo et al., 2019; Teney, 2019; Gomes et al.,2018; Giurgiuca, A. et al., 2018).

A future direction on which all EU Member States should focus is the harmonization of fiscal, economic, social and migration policies. It is necessary to ensure an attractive environment for foreign investments. This can happen when emigrants return to their country of origin, with new skills and knowledge, to lead to business development and exit from the underground economy. This will lead to the development of entrepreneurial thinking, which will inevitably increase the economy of the country over time. In the long run, we can think at the transition of emerging economies to developed ones. However, these goals depend mainly on the political environment of the countries concerned, financial, economic and national transparency, both individuals and governmental.

Taking into account the analyzed period and the analyzed variables, the study has some limitations. For example, we did not include factors such as political stability, corruption, economic stability, public debt, tax bases, number of employees, etc.

For a more in-depth study of the influence of migration on fiscal policies and fiscal systems of states, for a future research direction, a thorough study of internal causes at the country level is needed, mainly under fiscal legislation, which entails economic, financial and social repercussions. 


\section{REFERENCES}

Auerbach, A. J., \& Oreopoulos, P. (1999). Analyzing the fiscal impact of US immigration. American Economic Review, 89(2), 176-180. DOI: $10.1257 /$ aer.89.2.176

Basile, R., Girardi, A., Mantuano, M. \& Russo, G. (2019). Interregional Migration of Human Capital and Unemployment Dynamics: Evidence from Italian Provinces. German Econ Rev, 20, e385-e414. doi:10.1111/geer.12172

Carling, J., \& Talleraas, C. (2016). Root causes and drivers of migration. Oslo: Peace Research Institute Oslo (PRIO), 1-44.

Cattaneo, M., et al. (2019). The Italian brain drain: cream and milk. Higher Education, 77(4), 603-622. DOI: 10.1007/s10734-018-0292-8

Clements, B., Kamil D., Vitor, G., et al. (2015). The Fiscal Consequences of Shrinking Populations. IMF Staff Discussion Note, International Monetary Fund, Washington. DOI: 10.5089/9781513544885.006

Cohen, J. (1988). Statistical power analysis for the behavioral sciences (2nd ed.). New Jersey: Lawrence Erlbaum http://www.sportsci.org/resource/stats/effectmag.html\#cohen

Cristea, L. A. (2019). Increasing the Quality of the Taxes and Fees Impact Assessment on the Romanian Economy. Quality-Access to Success, 20, 497. WOS:000459686300087

Cseh Papp, I., Bilan, S., \& Dajnoki, K. (2019). Globalization of the Labour Market-Circular Migration in Hungary. Journal of International Studies, 12(2), 182-200. doi:10.14254/2071-8330.2019/12-2/11

Durbin, J. (1954). Errors in variables. Review of the International Statistical Institute, 22(1/3), 23-32. doi:10.2307/1401917.

European Comission, Eurostat-statistic explained, Data on taxation, available on https://ec.europa.eu/taxation_customs/business/economic-analysis-taxation/data-taxation_en

European Comission, Eurostat-statistic explained, Government expenditure on social protection, available on https://ec.europa.eu/eurostat/statistics-

explained/index.php/Government_expenditure_on_social_protection\#Expenditure_on_.27social_protection. 27.

Gabszewicz, J., et. al. (2016). Migration, wages and income taxes. International Tax and Public Finance, Springer; International Institute of Public Finance, 23(3), 434-453. doi: 10.1007/s10797-015-9370-3.

Gibson, J. \& McKenzie, D., (2012). The Economic Consequences of 'Brain Drain' of the Best and Brightest: Microeconomic Evidence from Five Countries. Economic Journal, 122, 339-375. https://doi.org/10.1111/j.14680297.2012.02498.x

Giurgiuca, A. et al. (2018). European Union Mobility, Income and Brain Drain. The Attitudes towards Migration of Romanian Psychiatric Trainees. Revista de Cercetare si Interventie Sociala, 63.

Glick Schiller, N. \& Faist, T., (2012). Migration, Development and Transnationalization. A Critical Stance, Oxford: Berghahn, 1-21.

Gnimassoun, B., \& Anyanwu, J. C. (2019). The Diaspora and economic development in Africa. Review of World Economics, Volume: 155 (4), pages: 785-817. DOI: 10.1007/s10290-019-00344-3.

Gomes, R. M., Lopes, J. T., Cerdeira, L., Vaz, H., et al..(2018). Asymmetric Mobility and Emigration of Highly Skilled Workers in Europe: The Portuguese case. Studia Migracyjne-Przeglad Polonijny, 3 (169), 143-164. DOI: 10.4467/25444972SMPP.18.040.9439.

Grenčíková, A., Španková, J., \& Habánik, J. (2017). Regional Disparities in Labor Force Migration abroad in Slovak Republic and in Czech Republic. Economics and Sociology, 10(3), 81-89. doi 10.14254/2071-789X.2017/10-3/6.

Griliches, Z., \& Hausman, J. A. (1986). Errors in variables in panel data. Journal of econometrics, 31(1), 93-118. https://doi.org/10.1016/0304-4076(86)90058-8.

Haapanen, M., \& Ritsilä, J. (2001). Can migration decisions be affected by income taxation policies?. In ERSA conference papers (No. ersa01p41). European Regional Science Association.

Hansen, M. F., Schultz-Nielsen, M. L., \& Tranæs, T. (2015). The Impact of Immigrants on Public Finances: A Forecast Analysis for Denmark. http://repec.iza.org/dp8844.pdf.

International Monetary Fund (2018). World Economic Outlook: Cyclical Upswing, Structural Change. Washington, DC, April.

IOM (2004). Glossary on Migration. International Migration Law. Geneva: International Organisation for Migration. 
Krause, A. (2017). On redistributive taxation under the threat of high-skill emigration. Social Choice and Welfare, 48(4), 845-856. https://doi.org/10.1007/s00355-017-1038-8.

Massey, D.S., et al. (2009) Worlds in Motion: Understanding International Migration at the End of the Millennium, Oxford: Oxford University Press.

Michael, M. S., \& Hatzipanayotou, P. (2001). Welfare effects of migration in societies with indirect taxes, income transfers and public good provision. Journal of Development Economics, 64(1), 1-24. https://doi.org/10.2139/ssrn.241440.

Nowrasteh, A. (2015). The fiscal impact of immigration. The Economics of Immigration: Market-Based Approaches, Social Science and Public Policy, 38-69.

OECD. (2018). International Migration Outlook 2018, OECD Publishing, Paris. https://doi.org/10.1787/migr_outlook-2018-en.

OECD. (2019). Tax revenue (indicator). doi: 10.1787/d98b8cf5-en.

Phyo, E. E., Goto, H., \& Kakinaka, M. (2019). International migration, foreign direct investment, and development stage in developing economies. Review of Development Economics, 23(2), 940-956. https://doi.org/10.1111/rode.12577.

Rowthorn, E. (2008). The fiscal impact of immigration on the advanced economies. Oxford Review of Economic Policy, 24(3), 560-580. https://doi.org/10.1093/oxrep/grn025.

Ruiz del Portal, X. (2017). Optimal mixed taxation, public goods and the problem of high-skilled emigration. Journal of Economics, Springer, 122(2), 97-119. doi: 10.1007/s00712-017-0536-6.

Simionescu, M. (2016). Macroeconomic determinants of permanent emigration from Romania: A Bayesian approach. Journal of International Studies, 9(2), 170-180. doi:10.14254/2071-8330.2016/9-2/13.

Simionescu, M. (2018). The impact of Brexit on the UK inwards FDI. Economics, Management and Sustainability, 3(1), 620. doi:10.14254/jems.2018.3-1.1

Simionescu, M., Bilan, Y., \& Mentel, G. (2017). Economic effects of migration from Poland to the UK. The Amfiteatru Economic Journal, 19(46), 757-770.

Simionescu, M., Bilan, Y., \& Gędek, S. (2019). Migration determinants and potential impact of Brexit on migration from the CEE Countries to the UK. Acta Polytechnica Hungarica, 16(7), 95-113.

Simionescu, M., Ciuiu, D., Bilan, Y., \& Strielkowski, W. (2016). GDP and net migration in some eastern and southeastern countries of Europe. A panel data and Bayesian approach. Montenegrin Journal of Economics, 12(2), 161. doi:10.14254/1800-5845.2016/12-1/10.

Stakanov, R. (2018). The role of regional migration policy in the development of migration processes. Economics, Management and Sustainability, 3(1), 70-78. doi:10.14254/jems.2018.3-1.7

Storesletten, K. (2000). Sustaining fiscal policy through immigration. Journal of political Economy, 108(2), 300-323. doi: 10.1086/262120.

Streimikiene, D., Bilan, Y., Jasinskas, E., \& Griksaite, R. (2016). Migration Trends in Lithuania and other New EU Member States. Transformations in Business \& Economics, 15(1), 21-33.

Strielkowski, W., \& Bilan, Y. (2016). Migration aspirations \& decisions: A comparative study of Turkey and Ukraine. Intellectual Economics, 10(1), 18-27.

Teney, C. (2019). Immigration of highly skilled European professionals to Germany: intra-EU brain gain or brain circulation?. Innovation: The European Journal of Social Science Research, 1-25. https://doi.org/10.1080/13511610.2019.1578197.

Thompson, J. (2011). The Impact of Taxes on Migration in New England. Political Economy Research Institute, 255-284.

Uprety, D. (2019). Does Skilled Migration Cause Income Inequality in the Source Country?. International Migration, doi: 10.1111/imig.12661.

Wallace, S. (2002). The effect of state income tax structure on interstate migration. Fiscal Research Center, Georgia State University. 